\title{
Intercontinental transport of nitrogen oxide pollution plumes
}

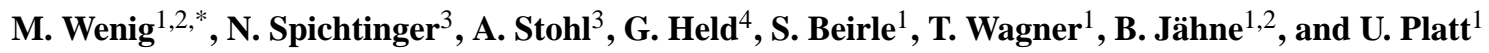 \\ ${ }^{1}$ Institut für Umweltphysik (IUP), Heidelberg University, Germany \\ ${ }^{2}$ Interdisziplinäres Zentrum für Wissenschaftliches Rechnen, Heidelberg, Germany \\ ${ }^{3}$ Lehrstuhl für Bioklimatologie und Immissionsforschung, TUM, Freising, Germany \\ ${ }^{4}$ Instituto Pesquisas Meteorológicas, Universidade Estadual Paulista, Brazil \\ *now at: NASA Goddard Space Flight Center, Greenbelt MD, USA
}

Received: 16 September 2002 - Published in Atmos. Chem. Phys. Discuss.: 19 November 2002

Revised: 14 February 2003 - Accepted: 19 March 2003 - Published: 3 April 2003

\begin{abstract}
We describe the first satellite observation of intercontinental transport of nitrogen oxides emitted by power plants, verified by simulations with a particle tracer model. The analysis of such episodes shows that anthropogenic $\mathrm{NO}_{x}$ plumes may influence the atmospheric chemistry thousands of kilometers away from its origin, as well as the ocean they traverse due to nitrogen fertilization. This kind of monitoring became possible by applying an improved algorithm to extract the tropospheric fraction of $\mathrm{NO}_{2}$ from the spectral data coming from the GOME instrument.

As an example we show the observation of $\mathrm{NO}_{2}$ in the time period 4-14 May, 1998, from the South African Plateau to Australia which was possible due to favourable weather conditions during that time period which availed the satellite measurement. This episode was also simulated with the Lagrangian particle dispersion model FLEXPART which uses $\mathrm{NO}_{x}$ emissions taken from an inventory for industrial emissions in South Africa and is driven with analyses from the European Centre for Medium-Range Weather Forecasts. Additionally lightning emissions were taken into account by utilizing Lightning Imaging Sensor data. Lightning was found to contribute probably not more than $25 \%$ of the resulting concentrations. Both, the measured and simulated emission plume show matching patterns while traversing the Indian Ocean to Australia and show great resemblance to the aerosol and $\mathrm{CO}_{2}$ transport observed by Piketh et al. (2000).
\end{abstract}

\section{Introduction}

Due to anthropogenic activities, the atmospheric trace gas composition has undergone significant changes during the past 100 years. In particular the tropospheric concentration of many trace species (e.g. of $\mathrm{O}_{3}, \mathrm{CO}, \mathrm{NO}, \mathrm{NO}_{2}, \mathrm{CH}_{4}$ ) has

Correspondence to: $\mathrm{M}$. Wenig

(wenig@code916.gsfc.nasa.gov) largely increased. Nitrogen oxides $\left(\mathrm{NO}_{x}=\mathrm{NO}+\mathrm{NO}_{2}\right)$ are key species in atmospheric chemistry and are heavily influenced by anthropogenic emissions. The availability of $\mathrm{NO}_{x}$ limits photochemical ozone formation in rural and remote regions (Lin et al., 1988; Chameides et al., 1992) and particularly in the upper troposphere (Levy et al., 1999), where the impact of ozone on radiative forcing is strongest (Johnson et al., 1992). $\mathrm{NO}_{x}$ also contributes to acid deposition from the atmosphere (Stoddard et al., 1999).

While the lifetime of $\mathrm{NO}_{x}$ in the atmospheric boundary layer (about 1 day) is too short to allow transport over long distances, its lifetime in the upper troposphere is of the order of 5-10 days (Jaeglé et al., 1998), which is sufficient even for intercontinental transport (Stohl et al., 2002). However, due to removal processes, transport of reactive nitrogen from the surface, where the largest sources are located, to the upper troposphere is inefficient (Murphy et al., 1993). Thus, weaker sources like lightning (Huntrieser et al., 1998; Brunner et al., 1998), aircraft emissions (Ziereis et al., 2000), recycling of $\mathrm{NO}_{x}$ from other nitrogen compounds, e.g. PAN or $\mathrm{HNO}_{3}$ (Wild, 1996), contribute to upper tropospheric $\mathrm{NO}_{x}$ in addition to transport from the surface.

Uncertainties in the upper tropospheric $\mathrm{NO}_{x}$ budget are substantial (Bradshaw et al., 2000). There have been only a few reports on long-range $\mathrm{NO}_{x}$ transport (Jeker et al., 2000). Although large-scale $\mathrm{NO}_{x}$ plumes were observed downwind of thunderstorms or frontal systems (Brunner et al., 1998), it was not possible to decide whether the $\mathrm{NO}_{x}$ originated from lightning or was lifted from the surface. Satellite measurements show that tropospheric $\mathrm{NO}_{2}$ is concentrated over industrial areas (Leue et al., 2001; Richter and Burrows, 2002; Velders et al., 2001). However, it is unclear what fraction of this $\mathrm{NO}_{x}$ reaches the free troposphere. Occasionally $\mathrm{NO}_{x}$ emissions from boreal forest fires can be transported several thousands of kilometres (Spichtinger et al., 2001), due to injection of the fire plume directly into the free troposphere.

In this paper, we present an episode of $\mathrm{NO}_{x}$ transport from

(C) European Geosciences Union 2003 


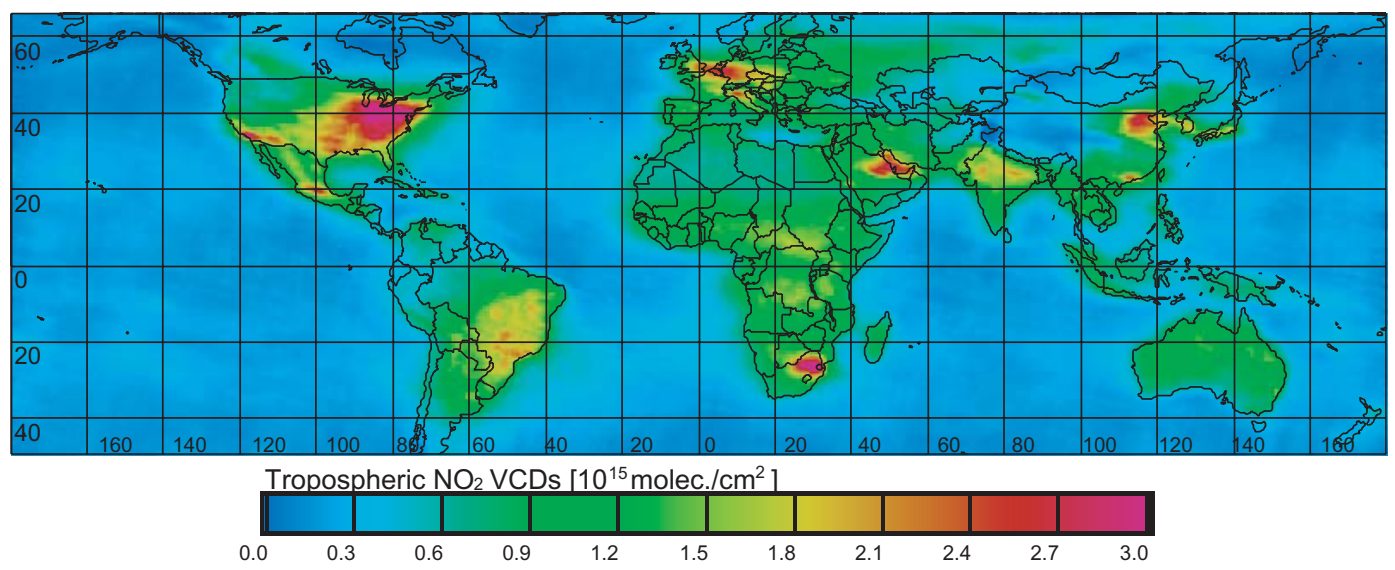

Fig. 1. Average annual tropospheric $\mathrm{NO}_{2}$ distribution (see Appendix A). For this image GOME data from 1996 to 2000 was used. Industrial areas in North America, Western Europe, North East China and South Africa are clearly visible, also Biomass burning in Africa and South America.

the South African (SA) Plateau (the Highveld area, 1400$1700 \mathrm{~m}$ asl) to Australia during May 1998. According to the Global Emissions Inventory Activity (GEIA) (Benkovitz et al., 1996) SA's $\mathrm{NO}_{x}$ emissions amount to approximately $370 \mathrm{kt} \mathrm{N} / \mathrm{y}$, which constitutes $1.8 \%$ of the worldwide anthropogenic emissions, in agreement with a regional inventory for the year 1993 (Wells et al., 1996).

\section{Industrial emissions over South Africa}

The highly industrialised Highveld region 1400-1700 m above sea level in the Mpumalanga Province accounts for $91 \%$ of SA's $\mathrm{NO}_{x}$ emissions (Wells et al., 1996; Held and Mphepya, 2000). Emission densities are among the highest in the world, with the second-highest emission grid cell in the GEIA inventory. More than $60 \%$ of the $\mathrm{NO}_{x}$ emissions in the Highveld region occur from stacks taller than $200 \mathrm{~m}$, and, in fact, most of these emissions originate from 8 large coal fired power plants and a synthetic fuel (from coal) processing complex, which are located in an area of roughly $200 \times 150 \mathrm{~km}^{2}$ in the Mpumalanga Province (Held et al., 1999).

The highest annual average tropospheric $\mathrm{NO}_{2}$ columns derived from GOME satellite data (Leue et al., 2001; Wenig, 2001) are found over industrial regions in the USA, Europe and East Asia. Other maxima exist over biomass burning regions. A distinct 'hot spot', with a magnitude comparable to $\mathrm{NO}_{2}$ columns at the North American east coast is also seen over the Highveld (Figs. 1 and 2), confirming the high $\mathrm{NO}_{x}$ emissions in this region. Normally this $\mathrm{NO}_{2}$ maximum is limited to the Highveld region, but in the GOME data we occasionally see export of $\mathrm{NO}_{2}$ over the Indian Ocean. A spectacular episode occurred in May 1998, when GOME data showed an $\mathrm{NO}_{2}$ plume travelling all the way from the Highveld region to Australia (Fig. 3). This was a very rare observation and could be measured with this explicitness for the first time since the launch of GOME in 1995. Biomass burning can be ruled out as a source of this plume because it normally does not occur during this season (Fishman et al., 1991) and no large fires were reported in May 1998.

\section{Intercontinental transport}

Until 6 May, the meteorological situation over SA was dominated by a subtropical high. This, associated with weak pressure gradients, is typical for SA and leads to an accumulation and re-circulation of pollutants (Held et al., 1994; Garstang et al., 1996), as well as to the formation of several inversion layers that limit the vertical dilution of air pollution (Zunckel et al., 2000). Starting on 6 May, a low-pressure system moved in from the west, yielding strong pressure gradients between this low and a subtropical high over the central Indian Ocean. This lead to fast export of air from SA towards the southeast between 7 and 9 May. This pathway dominates especially during the southern hemispheric winter (Sturman et al., 1997). For the May 1998 episode it was important that before the onset of strong westerly winds, air pollution could accumulate in the subtropical high and was lifted to the upper troposphere ahead of the cold front pulling in from the west. Fast winds at higher altitudes then carried this air towards Australia.

We simulated the evolution of the $\mathrm{NO}_{x}$ plume with the particle dispersion model FLEXPART (see Appendix B) in order to validate that the $\mathrm{NO}_{2}$ plume seen in the GOME data indeed originated from the Highveld industrial sources. Both the GOME data and the FLEXPART results show a plume that travels from SA (4 May) southeastward over the Indian Ocean, passes south of Madagascar (8 May) and then floats zonally towards Australia (10-14 May). The evolution of the plume over several days is similar in both, the GOME data 

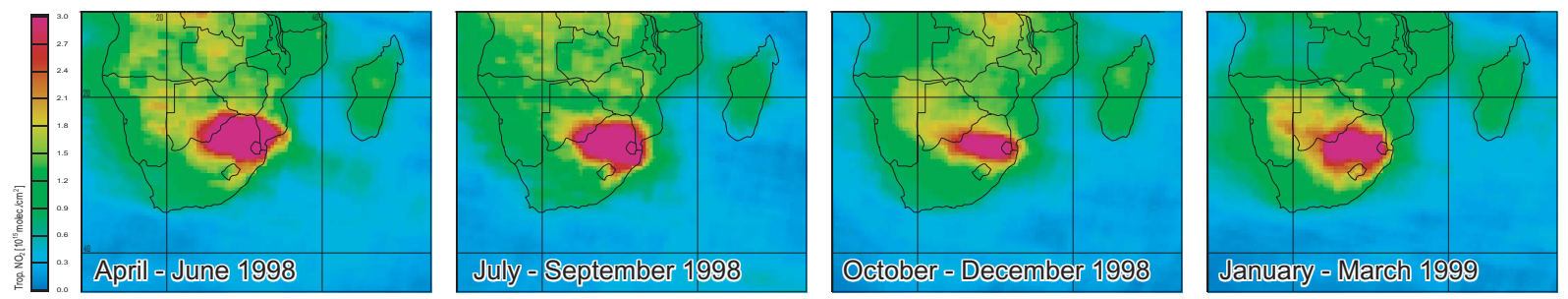

Fig. 2. Seasonal tropospheric $\mathrm{NO}_{2}$ distribution of SA for 1998

and the model simulation, except that clouds partly mask the plume from satellite detection. The clouds form because of the strong uplifting of air ahead of the cold front associated with the low pressure system. With this ascending airstream (the so-called warm conveyor belt) $\mathrm{NO}_{x}$ tracer reaches altitudes above $10 \mathrm{~km}$ (Fig. 3, right column). This upward transport, apart from cloud formation, fully exposes the plume to GOME, as the sensitivity of this instrument increases with altitude. In contrast, close to the source the $\mathrm{NO}_{x}$ plume is at low altitudes, where haze may reduce the fraction of the $\mathrm{NO}_{2}$ column seen by the instrument. This leads to a low $\mathrm{NO}_{2}$ sensitivity of GOME. In Fig. 3, left column, the development of the $\mathrm{NO}_{2}$ plume measured by GOME is shown, where areas with high cloud cover are marked by hashed areas. Clouds can have different influence of the measurement, they can increase the signal for $\mathrm{NO}_{2}$ lying above the cloud, e.g. coming from lightning events, and they can shield parts of the $\mathrm{NO}_{2}$ lying beneath the cloud. Considering this, the GOME $\mathrm{NO}_{2}$ fit very well to the modeled results. The FLEXPART simulations were performed using different $\mathrm{NO}_{2}$ life times in order to use the results with the closest match to GOME, leading to an $\mathrm{NO}_{2}$ life time of 4 days. The FLEXPART simulations include only the constant source over the Highveld area as well as various lightning sources, marked by circles in Fig. 3, but no sources over Australia, which explains higher $\mathrm{NO}_{2}$ monitored by GOME in Fig. 3h and i.

Inspection of the GOME data set reveals that similar plume transports are rarely found in other parts of the world, including the high-emission regions at the North American and Asian East coasts. Several factors favoured the formation and also the clear detection of the discussed plume:

First, $\mathrm{NO}_{x}$ emission densities in the Highveld are among the highest in the world. Second, with an altitude of 1400 to $1700 \mathrm{~m}$ above sea level the Highveld is one of the most elevated industrial regions worldwide. In addition, buoyant emissions from tall stacks are usually lifted above the ground-based, nocturnal inversions (Held et al., 1996). This reduces chemical losses and dry deposition of $\mathrm{NO}_{x}$. Third, during anticyclonic conditions, such as those prevailing during May 1998, several inversion layers are created, pollutants get trapped between them (Tyson et al., 1997) and the pollutant's entrainment within the boundary layer is prevented. Pollution export occurs effectively only when a low-pressure system sweeps over SA - this happened in our case on 6-
7 May - and leads to transport towards the Indian Ocean and Australia (Piketh et al., 1999; Tyson and D'Abreton, 1998). If transported off-shore, polluted airmasses from the Highveld travel above the marine boundary layer (Tyson and D'Abreton, 1998). Figure 3, right column, indicates that the major part of the $\mathrm{NO}_{x}$ plume was decoupled from the surface.

Another aspect of the low-pressure system are thunderstorms which formed due to the strong frontal ascent. Therefore, lightning is expected to have contributed to the $\mathrm{NO}_{x}$ plume travelling to Australia. In Fig. 3, left column, the positions of lightning flashes observed by the Lightning Imaging Sensor (LIS) are marked by circles. The power plant plume started already west of the flash locations. The latter were due to thunderstorms developing in the weak low pressure zone stretching from Gough Island $\left(40^{\circ} 21^{\prime} \mathrm{S}, 09^{\circ} 53^{\prime} \mathrm{W}\right)$ along the South African coast to Maputo $\left(25^{\circ} 58^{\prime} \mathrm{S}, 32^{\circ} 35^{\prime} \mathrm{E}\right)$ on 6 May, subsequently moving eastward over the Indian Ocean. On the basis of the LIS data set we additionally simulated lightning $\mathrm{NO}_{x}$ with FLEXPART (see Appendix B). Most of the lightning is observed over open ocean which is known to produce substantially more cloud to cloud flashes (Pickering et al., 1998) than over land, with correspondingly less $\mathrm{NO}_{x}$ produced. Rutledge et al. (1992) showed evidence that a high flash rate correlates to a higher IC/CG ratio. Therefore the contribution of lightning $\mathrm{NO}_{x}$ to the traveling plume is very likely not the dominant fraction, even with this high number of flashes observed by LIS. This can be verified by comparing areas of high $\mathrm{NO}_{2}$ concentration not coinciding with high cloud cover. Nevertheless the estimation of lightning $\mathrm{NO}_{x}$ is very uncertain. The storm observed by LIS on 11 May over Australia is omitted in the simulation in order to focus on the transported $\mathrm{NO}_{2}$. The column density of the resulting lightning $\mathrm{NO}_{x}$ is around $25 \%$ of the portion due to power plant.

Quantitative comparisons between satellite and model data are difficult because of the varying sensitivity of GOME to tropospheric $\mathrm{NO}_{2}$. Furthermore, FLEXPART does not separate $\mathrm{NO}_{x}$ into $\mathrm{NO}$ and $\mathrm{NO}_{2}$ and does not account for chemical transformations. 
GOME tropospheric $\mathrm{NO}_{2}$
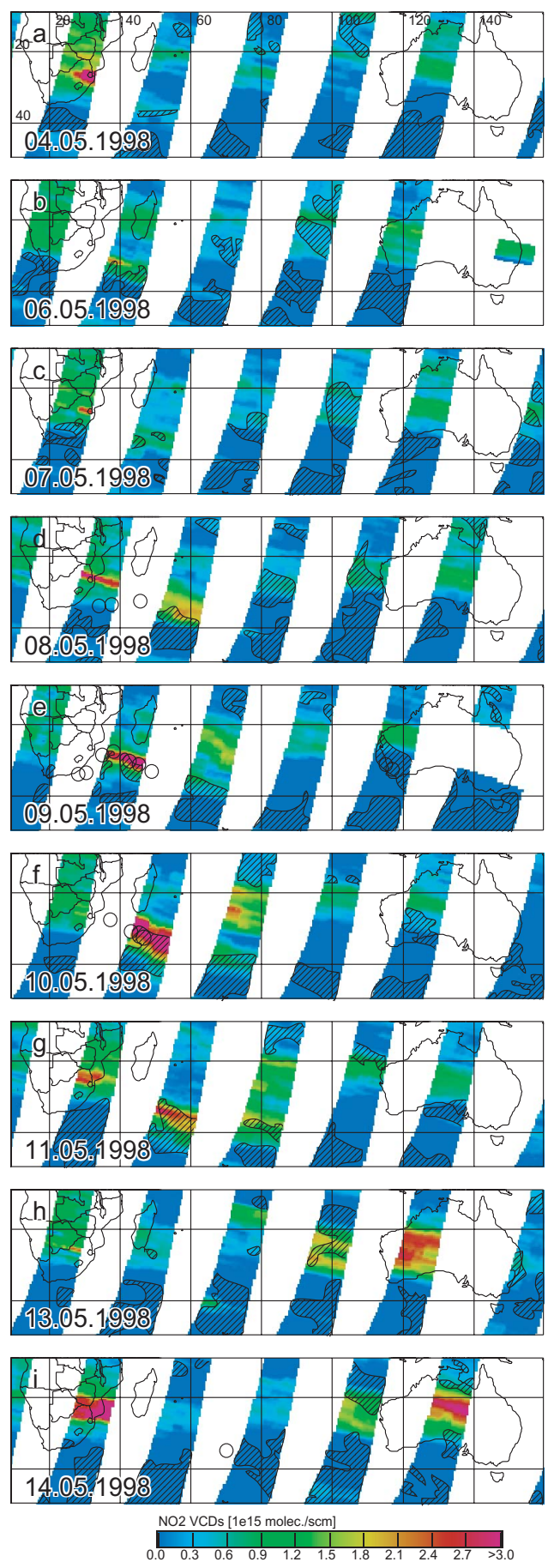

Flexpart $\mathrm{NO}_{x}$ tracer
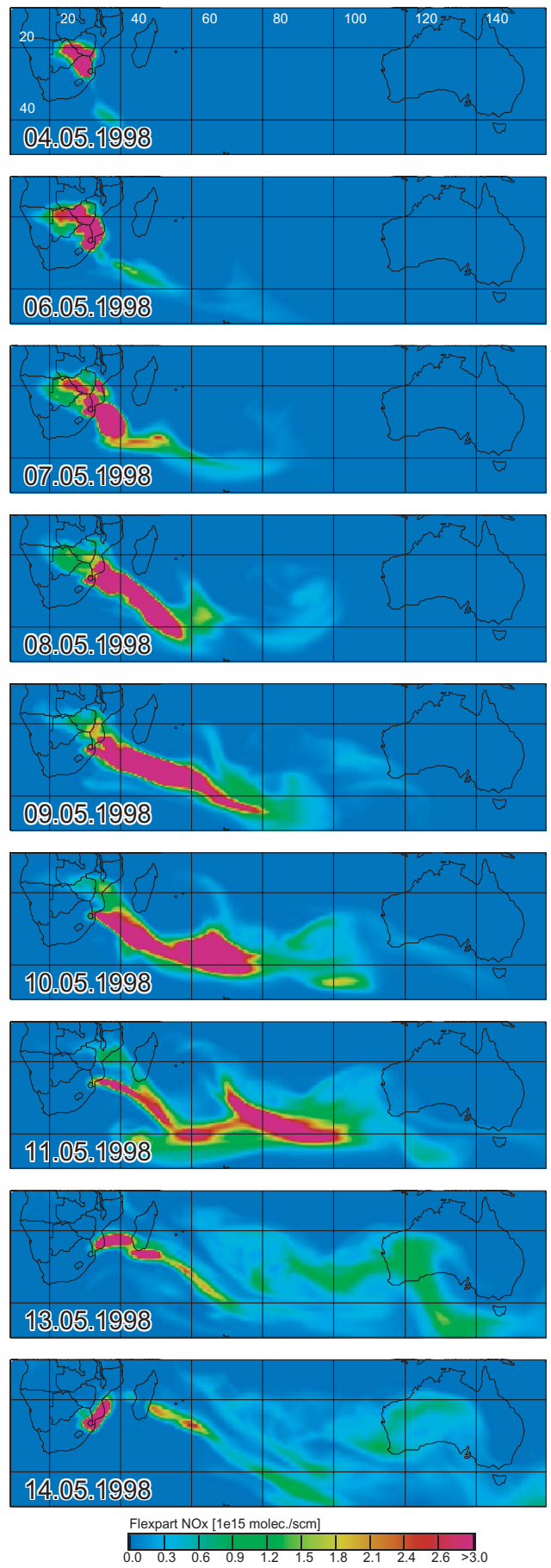
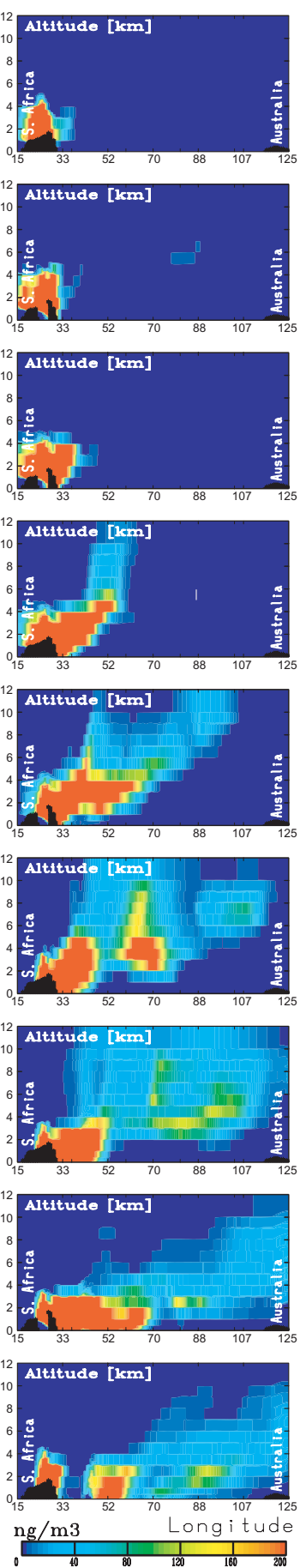

Fig. 3. Sequence of distributions of tropospheric $\mathrm{NO}_{2}$ columns from the GOME instrument east of SA in May 1998 (left column). For the extraction of the tropospheric fraction of $\mathrm{NO}_{2}$ the stratosphere/troposphere separation algorithm (Wenig, 2001) was used. Areas with high cloud cover $(>50 \%)$ are marked by hashed areas and high lightning activity ( $>50$ flashes per grid cell) are marked by circles. Corresponding $\mathrm{NO}_{x}$ tracer column densities including emissions from lightning (centre column) and vertical sections of the $\mathrm{NO}_{x}$ tracer concentrations only for industrial emissions, averaged between 20 and 45 degrees southern latitude (right column), obtained with FLEXPART (see Appendix B). 


\section{Conclusions}

Our investigation indicates that the $\mathrm{NO}_{2}$ plume detected by the GOME instrument, is coming from power plant emissions and is mixed with lightning induced $\mathrm{NO}_{2}$ over the Indian Ocean near South Africa. Due to the special meteorological situation, the industrial emissions could leave the South African continent and travel towards Australia, decoupled from the marine boundary layer. Ozone formation in power plant plumes, which are deficient in hydrocarbons, depends strongly on the entrainment of ambient air into the plume (Ryerson and et al., 2001). With a $\mathrm{NO}_{x}$ residence time equal to four days we observed in this case, the plume will be strongly mixed with ambient air, enhancing the ozone forming capacity of the power plant $\mathrm{NO}_{x}$. Intercontinental transport of $\mathrm{NO}_{x}$ from SA industrial sources in combination with lightning $\mathrm{NO}_{x}$ produced over the Indian Ocean can thus have implications for Australia's ozone budget and possibly other parts of the Southern Hemisphere.

Acknowledgements. This study is part of our project NOXTRAM which is funded as part of the German Atmospheric Research Program (AFO 2000) by the German Federal Ministry for Education and Research which we gratefully acknowledge.

Partial support was also provided by the DFG research unit "Image Sequence Analysis to Investigate Dynamic Processes”.

We thank the Deutscher Wetterdienst for kindly providing access to ECMWF data.

Lightning Data was provided by the Global Hydrology Resource Center (GHRC) at the Global Hydrology and Climate Center, Huntsville, Alabama.

Thanks are due to Paul James for the extraction of the ECMWF windfields, which we needed to run FLEXPART.

We also thank the South African Weather Service for making copies of surface and upper atmosphere maps, as well as relevant radiosonde data, available during the study period.

\section{Appendix A: The Global Ozone Monitoring Experiment}

In April 1995 the ERS-2 satellite was launched by the European Space Agency (ESA). The satellite carries, in addition to other instruments, the Global Ozone Monitoring Experiment (GOME) (see Burrows et al., 1999), an instrument designed to measure trace gas abundances in the atmosphere using the technique of Differential Optical Absorption Spectroscopy (DOAS) (see e.g. Platt, 1994). In order to analyze the transport of anthropogenic $\mathrm{NO}_{2}$ a stratosphere/troposphere separation algorithm based on image processing techniques was used as we are interested in tropospheric $\mathrm{NO}_{2}$ (see also Leue et al., 2001; Wenig, 2001). The data can be found at http://satellite.iup.uni-heidelberg.de.

\section{Appendix B: FLEXPART}

FLEXPART is a Lagrangian particle tracer model with a highly accurate transport scheme (Stohl et al., 1998) that is driven with analyses from the European Centre for MediumRange Weather Forecasts. Transport of a $\mathrm{NO}_{x}$ tracer was simulated, for which 1 million tracer particles were released according to the $\mathrm{NO}_{x}$ emissions taken from an inventory for industrial emissions in SA (Wells et al., 1996; Held and Mphepya, 2000). Additionally, to determine lightning produced NOx, we used Lightning Imaging Sensor (LIS) data to get the number and locations of flashes. We assumed $6.7 \times$ $10^{25}$ molecules NO/flash for IC flashes, $6.7 \times 10^{26}$ molecules $\mathrm{NO} /$ flash for CG flashes (Jourdain and Hauglustaine, 2001; Beirle et al., 2002) and the fraction of CG flashes to be 5\%. The resulting numbers of molecules were scaled by a factor of 500, corresponding to 2 LIS overpasses per day with 90 seconds viewing time respectively, apportioned to 1 million lightning $\mathrm{NO}_{x}$ tracer particles and released between 5 and $10 \mathrm{~km}$ height. Other $\mathrm{NO}_{x}$ sources in $\mathrm{SA}$ are much smaller (Wells et al., 1996) and were neglected. Chemical transformations were not accounted for, but a tracer lifetime of 4 days was applied. More information on FLEXPART is available from http://www.fw.tum.de/EXT/LST/METEO/stohl/

\section{Appendix C: The Lightning Imaging Sensor}

The Lightning Imaging Sensor (LIS), is a space based instrument used to detect the distribution and variability of total lightning that occurs in the tropical regions of the globe. http://thunder.nsstc.nasa.gov/data/

\section{References}

Beirle, S., Hollwedel, J., Kraus, S., Wagner, T., Wenig, M., WilmsGrabe, W., and Platt, U.: Estimation of $\mathrm{NO}_{2}$ emissions from lightning and biomass burning: A case study using tropospheric NO2-data derived from GOME, submitted to proceedings: "Air pollution" 2002, WIT Press, 2002.

Benkovitz, C. M., Scholtz, M. T., Pacyna, J., Tarrason, L., Dignon, J., Voldner, E.C., Spiro, P. A., Logan, J. A., and Graedel, T.E.: Global gridded inventories of anthropogenic emissions of sulfur and nitrogen, J. Geophys. Res., 101, 29239-29 254, 1996.

Bradshaw, J., Davis, D., Grodzinsky, G., Smyth, S., Newell, R., Sandholm, S., and Liu, S.: Observed distributions of nitrogen oxides in the remote free troposphere from the NASA Global Tropospheric Experiment programs, Rev. Geophys., 38, 61-116, 2000.

Brunner, D., Staehelin, J., and Jeker, D.: Large-scale nitrogen oxide plumes in the tropopause region and implications for ozone, Science, 282, 1305-1309, 1998.

Burrows, J., Weber, M., Buchwitz, M., Rozanov, V., LadstätterWeißenmayer, A., Richter, A., DeBeek, R., Hoogen, R., Bramstedt, K., Eichmann, K.-U., Eisinger, M., and Perner, D.: The Global Ozone Monitoring Experiment (GOME): Mission con- 
cept and first scientific results, J. Atmos. Sci., 56, 151-175, 1999.

Chameides, W.L., Fehsenfeld, F., Rodgers, M. O., Cardelino, C., Martinez, J., Parrish, D., Lonneman, W., Lawson, D. R., Rasmussen, R. A., Zimmerman, P., Greenberg, J., Middleton, P., and Wang, T.: Ozone precursor relationships in the ambient atmosphere, J. Geophys. Res., 97, 6037-6055, 1992.

Fishman, J., Fakhruzzaman, F., Cros, B., and Nganga, D.: Identification of widespread pollution in the Southern Hemisphere deduced from satellite analysis, Science 252, 1305-1309, 1991.

Garstan, M., eTyson, M. P., Swap, R., Edwards, M., Källberg, P., and Lindesay, J.: Horizontal and vertical transport of air over southern Africa, J. Geophys. Res., 101, 23 721-23 736, 1996.

Held, G. and Mphepya, J.: Wet and dry deposition in South Africa, Proceedings, XI Congresso Brasiliero de Meteorologia (CDROM), SBMET, Rio de Janeiro, 16-20 Outubro 2000, Paper QA00002, pp. 2824-2833, 2000.

Held, G., Scheifinger, H., and Snyman, G.: Recirculation of pollutants in the atmosphere of the South African Highveld, SA J. of Science, 90, 91-97, 1994.

Held, G., Scheifinger, H., Snyman, G., Tosen, G., and Zunckel, M.: The climatology and meteorology of the Highveld (Chapter 9 in: Air pollution and its impacts on the South African Highveld, (Eds) Held, G., Gore, B. J., Surridge, A. D., Tosen, G. R., Turner, C. R., and Walmsley, R. D., 60-71, Environmental Scientific Association, Cleveland, pp. 144, 1996.

Held, G., Snyman, G., and Pienaar, J.: Vertical distribution of pollutants over the Mpumalanga Highveld (Summary 1994-1998), Eskom Report RES/RR/99/00087, pp. 64, Johannesburg, 1999.

Huntrieser, H., Schlager, H., Feigl, C., and Höller, H.: Transport and production of $\mathrm{NO}_{x}$ in electrified thunderstorms: Survey of previous studies and new observations at midlatitudes, J. Geophys. Res. 103, 28 247-28 264, 1998.

Jaeglé, L., Jacob, D. J., Wang, Y., Weinheimer, A. J., Ridley, B. A., Campos, T.L., Sachse, G.W., and Hagen, D. E.: Sources and chemistry of $\mathrm{NO}_{x}$ in the upper troposphere over the United States, Geophys. Res. Let. 25, 1705-1708, 1998.

Jeker, D., Pfister, L., Thompson, A., Brunner, D., Boccippio, D., Pickering, K., Wernli, H., Kondo, Y., and Staehelin, J.: Measurements of nitrogen oxides at the tropopause: Attribution to convection and correlation with lightning, J. Geophys. Res., 105, D3, 3679-3700, 2000.

Johnson, C., Henshaw, J., and McInnes, G.: Impact of aircraft and surface emissions of nitrogen oxides on tropospheric ozone and global warming, Nature, 355, 69-71, 1992.

Jourdain, L. and Hauglustaine, D.: The global distribution of lightning NOx simulated in a general circulation model, Phys. Chem. Earth (C), 26, 585-591, 2001.

Leue, C., Wenig, M., Wagner, T., Klimm, O., Platt, U., and Jähne, B.: Quantitative analysis of $\mathrm{NO}_{x}$ emissions from Global Ozone Monitoring Experiment satellite image sequences, J. Geophys. Res., 106, D6, 5493-5505, 2001.

Levy, H., II, Moxim, W. J., Klonecki, A. A., and Kasibhatla, P. S.: Simulated tropospheric $\mathrm{NO}_{x}$ : Its evaluation, global distribution and individual source contributions, J. Geophys. Res., 104, 26 279-26306, 1999.

Lin, X., Trainer, M., and Liu, S. C.: On the nonlinearity of the tropospheric ozone production, J. Geophys. Res., 93, 15 879-15 888, 1988.
Murphy, D., Fahey, D., Profitt, M., Liu, S., Chan, K., Eubank, C., Kawa, S., and Kelly, K.: Reactive nitrogen and its correlation with ozone in the lower stratosphere and upper troposphere, J. Geophys. Res., 98, 8751-8773, 1993.

Pickering, K., Wang, Y., Tao, W.-K., Price, C., and Müller, J.-F.: Vertical distribution of lightning $\mathrm{NO}_{x}$ for use in regional and global chemical transport models, J. Geophys. Res., 103, D23 31 203-31 216, 1998.

Piketh, S., Annegarn, H., and Tyson, P.: Lower tropospheric aerosol loadings over South Africa: the relative contribution of aeolian dust, industrial emissions, and biomass burning, J. Geophys. Res., 104, 1597-1607, 1999.

Piketh, S., Tyson, P., and Steffen, W.: Aeolian transport from southern Africa and iron fertilization of marine biota in the South Indian Ocean, S. African J. of Science, 96, 244-246, 2000.

Platt, U.: Differential optical absorption spectroscopy (DOAS), in: Air Monitoring by Spectrometric Techniques, (Ed) Sigrist, M., vol. 127 of Chemical Analysis Series, pp. 27-84, John Wiley, New York, 1994.

Richter, A. and Burrows, J.: Retrieval of tropospheric $\mathrm{NO}_{2}$ from GOME measurements, Adv. Space Res., 29 (11), 1673-1683, 2002.

Rutledge, S. A., Williams, E. R., and Keenan, T. D.: The Down Under Doppler and Electricity Experiment (DUNDEE): Overview and preliminary results, Bull. Amer. Meteor. Soc., 73, 3-16, 1992.

Ryerson, T. B., Trainer, M., Holloway, J. S., Parrish, D. D., et al.: Observations of ozone formation in power plant plumes and implications for ozone control strategies, Science, 292, 719-723, 2001.

Spichtinger, N., Wenig, M., James, P., Wagner, T., Platt, U., and Stohl, A.: Satellite detection of a continental-scale plume of nitrogen oxides from boreal forest fires, Geophys. Res. Let., 28, 4579-4583, 2001

Stoddard, J. L., Jeffries, D. S., Lükewille, A., Clair, T. A., Dillon, P. J., Driscoll, C. T., Forsius, M., Johannessen, M., Kahl, J.S., Kellogg, J. H., Kemp, A., Mannio, J., Monteith, D. T., Murdoch, P. S., Patrick, S., A., Rebsdorf, Skjelkvale, B. L., Stainton, M. P., Traaen, T., van Dam, H., Webster, K. E., Wieting, J., and Wilander, A.: Regional trends in aquatic recovery from acidification in North America and Europe, Nature, 401, 575-578, 1999.

Stohl, A., Hittenberger, M., and Wotawa, G.: Validation of the Lagrangian particle dispersion model FLEXPART against large scale tracer experiment data, Atmos. Environ., 24, 4245-4264, 1998.

Stohl, A., Eckhardt, S., Forster, C., James, P., and Spichtinger, N.: On the pathways and timescales of intercontinental air pollution transport, J. Geophys. Res., 107(D23), 4684, doi:10.1029/2001JD001396, 2002.

Sturman, A., Tyson, P., and D'Abreton, P.: A preliminary study of the transport of air from Africa and Australia to New Zealand, J. Royal Soc. New Zealand, 27, 4, 485-498, 1997.

Tyson, P., Garstang, M., Thompson, A., D’Abreton, P., Diab, R., and Browell, E.: Atmospheric transport and photochemistry of ozone over central Southern Africa during the Southern Africa Fire-Atmosphere Research Initiative, J. Geophys. Res., 102, $10623-10635,1997$.

Tyson, P. D. and D'Abreton, P.C.: Transport and recirculation of aerosols off Southern Africa - macroscale plume structure, At- 
mos. Environ., 32, 1511-1524, 1998.

Velders, G., Granier, C., Portmann, R., Pfeilsticker, K., Wenig, M., Wagner, T., Platt, U., Richter, A., and Burrows, J.: Global tropospheric $\mathrm{NO}_{2}$ column distributions: Comparing 3-D model calculations with GOME measurements, J. Geophys. Res., 106, 12 643-12 660, 2001.

Wells, R., Lloyd, S., and Turner, C.: National air pollution source inventory, in: Air pollution and its impacts on the South African highveld, (Eds) Held, G., Gore, B. J., Surridge, A. D., Tosen, G. R., Turner, C. R., and Walmsley, R. D., 3-9, Environmental Scientific Association, Cleveland, 1996.

Wenig, M.: Satellite Measurement of Long-Term Global Tropo- spheric Trace Gas Distributions and Source Strengths - Algorithm Development and Data Analysis, Ph.D. thesis, University of Heidelberg, 2001.

Wild, O.: Photochemical trajectory modeling studies of the North Atlantic region during August 1993, J. Geophys. Res., 101, 29 269-29288, 1996.

Ziereis, H., Schlager, H., Schulte, P., van Velthoven, P. F. J., and Slemr, F.: Distribution of $\mathrm{NO}, \mathrm{NO}_{x}$, and $\mathrm{NO}_{y}$ in the upper troposphere and lower stratosphere between $28^{\circ}$ and $61^{\circ} \mathrm{N}$ during POLINAT 2, J. Geophys. Res., 105, 3653-3664, 2000.

Zunckel, M., Robertson, L., Tyson, P., and Rodhe, H.: Modelled transport of sulphur over Southern Africa, Atmos. Environ., 34, 2797-2808, 2000. 